\title{
Consumer Reactions to Technological Attributes in Product Design: A Technology Acceptance Model Perspective
}

\author{
Ahmet Şekerkaya* \\ Istanbul University
}

\author{
Feyza Nur Özkan** \\ Istanbul University
}

\author{
Gözde Güsan Köse*** \\ Marmara University
}

\author{
Doğan Akarsu***** \\ Istanbul University
}

\begin{abstract}
This study aims firstly to determine the differences in effects between perceived usefulness and ease of use, attitude, and behavioral intention towards a product. The focus will be on the use of a technological attribute in product design in the frame of the technology acceptance model. Secondly, this study aims to examine whether or not these effects differ according to product type. Four different questionnaire forms were designed using the scenario technique and experimental design. The research data were collected from 504 people by a face-to-face survey method. The data were subjected to MANOVA and Multiple Group Structural Equation Modeling. As a result of this research, it was found that the effects among the variables within the technology acceptance model were significant. When the obtained model is evaluated according to the product design and product type, it is concluded that the model differs in the case of using a technological attribute in product design, but does not differ according to product type, and the model was valid for all product types.
\end{abstract}

Keywords: Product Design, Technological Attribute, Technology Acceptance Model, Structural Equation Modeling, Experimental Design

JEL Classification: M31

\section{Ürün Tasarımındaki Teknolojik Özelliklere Yönelik Tüketici Tepkileri: Bir Teknoloji Kabul Modeli Perspektifi}

\section{Özet}

Bu çalışmanın amacı, ürün tasarımında teknolojik özellik kullanımının teknoloji kabul modeli çerçevesinde ürünün algılanan faydası, ürünün algılanan kullanım kolaylığı, ürüne yönelik tutum ve davranışsal niyet arasındaki etkilerde oluşturduğu farklılıkların belirlenmesidir. Ayrıca bu etkilerin ürünün beğenmeli ve özellikli ürün olma durumuna göre farklılaşıp farklılaşmadığının belirlenmesi de araştırmanın amaçları arasında yer almaktadır. Deneysel tasarım yöntemiyle senaryo tekniğinden yararlanılarak dört farklı anket formu oluşturulmuştur. Yüz yüze anket metoduyla 504 kişiden toplanan veriler MANOVA analizi ve Çoklu Grup Yapısal Eşitlik Modeli ile test edilmiştir. Araştırma sonucunda teknoloji kabul modeli

\footnotetext{
* Ahmet Şekerkaya. Professor, Istanbul University, School of Business, Department of Marketing. Avcilar 34320, Istanbul, Turkey. E-mail: draseker@istanbul.edu.tr. Phone: +90 2124400000 (18258). ORCID: 0000-0002-4885-5134

** Feyza Nur Özkan. Corresponding Author. Research Assistant, Istanbul University, School of Business, Department of Marketing. Avcılar 34320, Istanbul, Turkey. E-mail: feyza.kamis@ istanbul.edu.tr. Phone: +90 2124400000 (18263). ORCID: 0000-0003-1346-3963

*** Gözde Güsan Köse. Research Assistant, Marmara University, Faculty of Business Administration, Business Administration Department, Department of Marketing. Work Address: Kadıköy 34180, Istanbul, Turkey. E-mail: gozde.gusan@marmara.edu.tr. Phone: +90 216449 5045. ORCID: 0000-0002-8792-9423

**** Doğan Akarsu. PhD Student, Istanbul University, Institute of Social Sciences, Marketing Program. E-mail: doganakarsu@ogr.iu.edu.tr. ORCID: 0000-0003-1201-5376
} 
kapsamındaki değişkenler arasındaki etkilerin anlamlı olduğu bulunmuştur. Elde edilen modelin ürün tasarımına ve ürünün türüne göre değişiklik gösterip göstermediği değerlendirildiğinde ise ürün tasarımı açısından modelin farklılaştığı ancak ürün türüne göre farklılık göstermediği ve modelin tüm ürün türleri için geçerliliğini koruduğu sonucuna ulaşılmıştır.

Anahtar Kelimeler: Ürün Tasarımı, Teknolojik Özellik, Teknoloji Kabul Modeli, Yapısal Eşitlik Modellemesi, Deney Tasarımı

JEL Sinıflandırması: M31

$\mathrm{T}$ The product, which is one of the elements of the marketing mix, comes to the forefront with its appearance and design. Recently, the importance of product design has increased, and since the 1930s, product design has been used in a more creative and strategic way to take advantage of the global market (Berkowitz, 1987; Nussbaum, 1988).

In order to maintain a competitive advantage for potential new designs, companies allocate resources and adapt a series of methods in highly competitive industrial environment (Unger and Eppinger, 2011). Evaluation of design concepts is the first and the most critical stage of the product development process, and a wrong design at this stage may lead to product redesign or remanufacturing (Okudan and Tauhid, 2008). Product design is important because it is one of the first criteria that consumers take into consideration during the evaluation of the product. Besides the functional benefit, the visual appeal of the product is becoming more important for consumers since these designs have started to differentiate in a wide range. Products give messages in terms of quality, ease of use, or benefit from their appearance and motivate consumers to use and exhibit them.

As technological developments penetrate social life with increasing speed, they have affected consumers and changed their consuming habits. These technological innovations also play a role in new product development in order to gain a competitive advantage and stand out in terms of both functionality and product design. Technological design, in terms of new product development, describes how different technological attributes interact to generate the product's functions (Henderson and Clark, 1990). According to Petkova and Rindova (2006), because consumers respond cognitively and emotionally to the aesthetic and symbolic features of a product, a product's form may have effects on consumers' value of product innovation perceptions.

The new forms of electronic products with technological attributes are one of the methods used by companies that are in intense competition to gain an advantage. It is seen that such products with high technology attributes increase visual appeal, and therefore, influence consumer responses (Lee et al., 2011). However, electronic products range from personal products to durable goods, and even to industrial products. We consider those customer responses to electronic product designs supported by technological attributes that will be different in such product types. Some consumers evaluate product functionalities differently and have different behavioral and attitudinal reactions (Ko et al., 2008). Technological attributes added to the products may have different effects depending on the type and usage area of the electronic product.

The current study aims to determine whether two different versions of the same product, with or without technological attributes, affect attitude and behavioral intentions on perceived usefulness and ease of use. Although there are rich resources on product design in the current literature, we believe there is a gap on the subject of perception differences created by the 
inclusion of technological attributes in product designs. If the design preferences between long term household products such as durable goods and relatively short-lived products vary (Creusen et al., 2010), it is worthwhile to find out the perceptional differences on such different types of products. In this study, which uses the Technology Acceptance Model as the main theory, durable household products were chosen as a product type, and these products were divided into two groups: shopping and specialty products. The extent to which the design perceptions of each product, with simple and technological attributes added, affect consumer attitudes and behavioral intentions in terms of perceived benefit and ease of use were measured.

\section{Conceptual Framework}

\section{Product Design}

In both professional and academic literature, the terms "design", "product design", "product design and development" and "industrial design" often mean the same or are equivalent (Mutlu and Er, 2003). The design has been considered as the most essential characteristic of the product (Bloch, 1995). As Walsh et al. (1988) indicated, with developments over time, the design creates a "strategy" for market success by increasing the quality of a product. Also, product design has been generally conceptualized as industrial design focusing on the shape and as technical design focusing the function of the product (Luchs and Swan, 2011; Unger and Eppinger, 2011). Although there is no consensus or common definition in the literature about the concept of product design, there are various approaches to this subject (Luchs and Swan, 2011). Er (1997), describes the product design as a strategic process that includes the information on how to embody and position the product in the market and imply essential "why" and "how" questions related to the particular product. The literature on product design includes such studies which focus solely on the shape (Bloch, 1995) or functionality (Kohli and Krishnamurti, 1987) of products. In the meantime, Luchs and Swan (2011) suggest that an integrated application is required for firm strategy and product success in the market. Verganti (2008) claims the design is related to the meanings that consumers place on products, and that these meanings express the symbolic and emotional value of products. Moreover, he argues that functionality focuses on satisfying the utilitarian needs of consumers while product meanings transmitted by product design were intended to meet emotional and sociocultural needs. In another study, where product design was discussed at three levels such as prototype, new and futuristic, it was found that there is no significant relationship between the innovation level in product design and emotional experiences, but there was a significant relationship between product design and cognitive evaluation (Gümüş and Gegez, 2020). The current tendency toward product design focuses on the consumer's making sense of the product rather than its functionality. According to this tendency, the needs and preferences of consumers are considered as primary concerns in product development in a highly competitive market (Krippendorff, 1989).

\section{The Use of Technological Attributes in Product Design}

Product innovation describes the changes in product features based on a modification in underlying technologies (Chandy and Tellis, 2000). The use of technology in product design also varies according to the speed of emerging technologies, and this change is categorized into two different levels; incremental and radical changes (Anderson and Tushman, 1990). Incremental changes can be described as small innovations which are still related to the current technological background, while drastic changes correspond to dramatic changes where technological fundamentals shift away (Benner and Tushman, 2003). Incremental innovations include a low level of technological change in product design, usually perceived well by consumers and they can adapt the new product easily. Since the changes in the product are 
limited, the new scheme of the product is consistent and easy to understand compared with the old one (Mandler, 1982). Another reason for the success of adaptation to incremental technological changes is the low degree of effort required. But Rindova and Petkova (2007) claim that because the familiarity and predictability of incremental changes trigger lowintensity positive emotions, its perceived value is believed to be limited. Meanwhile, since radical innovations create significant changes in the underlying technology of the product, it causes severe incongruity (Henderson and Clark, 1990). As the discrepancy generated by product innovation increases, the uncertainty about the potential impacts of the products, and the difficulty of understanding the potential value of the products will increase. But at the same time, this same uncertainty may likely cause more intense emotional reactions in consumers (Rindova and Petkova, 2007). To overcome this problem, the incongruity must be transformed into positive emotions by explaining the radical innovations to the customers in an effective way (Mugge and Dahl, 2013).

Consumers now consider features such as ease of use, functionality, affordability, attractiveness, recyclability, and safety as a standard, and expect more from a product (Demirbilek and Sener, 2003). Correspondingly, product design trends that inspire consumers and help evoke various emotions start to emerge (Alessi, 2000; Jensen, 1999). Product designs with a technological attribute are one of these trends. In Sadik-Rozsnyai and Bertrandias' (2019) study, consumers with a high degree of social innovativeness are willing to pay a price premium when they perceive value from a new technological attribute. According to the study, socially innovative consumers interpret a technological attribute in product design as an opportunity to differentiate themselves from others. As consumers' relationship with technology evolves, such product designs have started to increase what is essential in this matter to determine to what degree of use of the technological attribute will affect consumer perceptions in a positive way and whether this effect is stable across specific product types.

\section{Technology Acceptance Model}

The Technology Acceptance Model (hereafter TAM) (Davis, 1989), a widely used model in the management of information systems, is an adaptation of the theory of justified action (Fishbein and Ajzen, 1975). TAM aims to provide a fundamental explanation of the determinants of technology adoption for the behavior of users in a broad range of technology innovations (Davis et al., 1989).

TAM explains theoretically that a person's behavioral intention to adopt a particular technology is determined by a person's attitude towards using the technology, and it argues that attitude is explained with perceived usefulness and perceived ease of use.

Perceived Usefulness: Perceived usefulness is defined as the degree of usefulness that an individual's use of a particular system contributes to business performance (Davis, 1989). It is seen that the perceived usefulness by individuals in the adaptation process they experience when they encounter a new technology plays a significant role in the effect on this adaptation. According to TAM, individuals' perceived usefulness of a new technology will have a direct effect on their attitudes towards that technology and later on their behavioral intentions to use that system.

Perceived usefulness appears to be an essential variable in studies investigating the adaptation of many systems using new technologies. It has been observed that perceived usefulness has a positive effect on behavioral intention in consumers' adaptation to smartphone use (Özbek et al., 2014; Park and Chen, 2007). In the study, where values perceived by consumers from wearable technologies are measured, it is seen that the perceived enjoyment by real customers has a more explanatory role in the effect on perceived value compared to 
perceived usefulness, and that the benefit perceived by potential customers is a more powerful factor on perceived value than perceived enjoyment (Yang et al., 2016).

Perceived Ease of Use: Perceived ease of use is the degree of individuals' adaptation to a system without effort (Davis, 1989). According to TAM, perceived ease of use has both a direct and indirect impact on consumers' intention to use a new system (Venkatesh, 1999). Because when individuals come across a new system, their adaptation to the use of this system effectively depends on their degree of learning. If the system is easy to learn and use, the adaptation of individuals to that system will be easier. Thus, the benefit perceived by individuals about a new system will be affected by the ease of using that system, and when all things are equal, the ease of using a system will increase the benefit from that system (Venkatesh and Davis, 2000).

Attitude: Attitude refers to the tendency of a person to react positively or negatively to an object, person, or event (İslamoğlu and Altunışık, 2013). When TAM is considered, it is explained that the utilitarian and hedonic sides of consumer experiences affect attitudes towards the product and attitudes are an important variable on behavioral intention (Davis et al., 1992). According to the purpose-directed behavior model, what affects these attitudes of individuals is their beliefs. Attitude is influenced by the diversity of these beliefs and affects individuals' orientation to behavior (Hill et al., 1977). If the general attitudes of individuals towards products develop positively, as the probability of this attitude to turn into behavior will increase, it is thought that attitudes towards different product models will be a significant factor in the adaptation process to these products.

Behavioral Intention: The willingness of people to use a particular service or system is defined as behavioral intention (Davis, 1989). While consumers' intentions towards behavior are seen as the last point in the adaptation process to a new system, the factors that push people to behavior can be defined as internal and external. Although perceptions of benefit and ease of use regarding the system are thought to be factors affecting intention, the characteristics, interest levels, and social characteristics of consumers, which generally affect the adaptation process, also play an important role. In individuals' adaptation to a technological product, the product's various characteristics as well as perceptions of the products' performance risk and economic risk may affect their intentions for use (Yang et al., 2016).

\section{Literature Review and Research Hypothesis Development}

The product, which is one of the marketing mix elements, can be defined as a collection of physical, service and symbolic qualities that provide satisfaction or usefulness to a user or buyer (Mugge and Dahl, 2013). Designing a new product is based on a problem-solving approach to improve end-users' quality of life and interaction with the environment. This problem solving is related to visualization and solution of the needs of the user (Talke et al., 2009).

Before judging the competitive innovation of a product based on the functionality, primarily the fact that the consumers meet with the visual appearance of the product strengthens the relationship between product innovation and visual design (Radford and Bloch, 2011). Since the physical performance of the product emerges after the visual encounter with the product, the design of the product gains meaning with its ability to transmit the product features (Hauser et al., 2006). The robust and strong appearance of durable goods is exemplified through the shape of a sailboat, which transmits speed and agility; or a new toy design, which points to its entertainment potential. However, the critical initial evaluation of innovation is expected to stop in visual design rather than enhanced functionality (Hollins and Pugh, 1990).

The present study has reexamined the following studies conducted in national and international literature within the scope of TAM; consumer reactions to product design in 
general, the way that design elements affect consumer perceptions, the effect on price sensitivity, and the attitudes and behaviors of consumers (Creusen et al., 2010; Crilly et al., 2004; Mugge and Dahl, 2013; Mumcu and Kimzan, 2015; Mutlu and Er, 2003; Nanda et al., 2008; Radford and Bloch, 2011; Tzou and Lu, 2009). It is seen that the visual design of the product has an essential and significant role in successful marketing studies, and "design" is a tool to reach competitive strategies in the marketing literature (Mutlu and Er, 2003; Veryzer, 1993). Porter (1980) defines common competition strategy types as "price", "focus" and "differentiation"; also in a competitive strategy based on "differentiation", "design" has been expressed as a strategic tool for product positioning for the targeted market segment (Mutlu and Er, 2003). "Design" offers differences in quality, durability, ease of use, appeal, and price that provides a competitive advantage to the product (Porter, 1980). Also, customer demand may have increased by changing the appearance or style of the products (Schmitt and Simonson, 1997). Besides, the significance of visual features and design of products for the emotional attachment of users have been highlighted in many studies about consumer acceptance of consumer electronics products (Cyr et al., 2006; Hsiao, 2013; Nanda et al., 2008). In Nanda et al. 's (2008) sample studies composed of users of mobile phones, it is concluded that the emotional reactions and preferences of the users were influenced by the aesthetic design of a mobile phone. It was conducted from a study that while evaluating the product designs of consumers, even though they did not know the characteristics of the design, changes in the product visual appearance affected consumers' perceptions (Moreau et al., 2001), and consumers had a more positive attitude towards products that exhibit more moderate and appropriate changes in visual design innovations (Goldenberg et al.,1999; Moreau et al., 2001; Rindova and Petkova, 2007). In another study, it was seen that consumers had more effective product and aesthetic expectations in the innovations in high-quality products (Arora and Arora, 2017). Talke et al. (2009), on the other hand, examined the effect of innovation and technological attributes on product performance in product design and concluded that sales performance was positively affected.

The marketing literature emphasizes that the appearance of a product affects not only the visual quality of design but also the perceived functional and ergonomic value of the product (Bloch, 1995; Creusen and Schoormans, 2005; Veryzer, 1993). Also, besides affecting aesthetic preferences, the visual design provides information about the ease of use, functionality, and quality perception (Veryzer and Hutchinson, 1998). In studies related to the complex and simple design of the product, a complex design has been found to adversely affect consumers' perception of ease of use (Cyr et al., 2006). Creusen and Schoormans (2005) investigated whether the preferred level of visual design principles depends on the type of product value, aesthetic value, functionality, quality (functional value), and ease of use. As a result of the study, it has been found that the products with low visual complexity affect the perception of product value, aesthetics, functionality, quality, and ease of use.

Davis (1985) stated that design features directly affect perceived usefulness and perceived ease of use in the context of TAM he has developed. He also stated that design features do not have a direct effect on attitudes and behaviors, but that design features indirectly affect attitudes and behaviors through perceived usefulness and perceived ease of use. In the Van der Heijden's (2003) study, which aims to explain individual acceptance of websites and use of websites within the scope of perceived visual attractiveness by using TAM (perceived usefulness, perceived ease of use, attitude), it has been concluded that perceived ease of use and perceived usefulness affect attitudes as a result of visual design aesthetics.

While perceived ease of use is defined as the degree to which a person believes that using a certain system does not require effort (Kulviwat et al., 2007), it is stated in TAM that behavioral intention is determined by individual attitude and this attitude is determined by 
perceived usefulness and perceived ease of use (Dabholkar and Bagozzi, 2002; Davis et al., 1989; Gentry and Calantone, 2002; Venkatesh, 1999). Considering the specificity of this research, it is thought that consumers' perceptions of ease of use, attitudes, and usage intention of products designed with technological attributes will have a positive effect. Considering that these attributes are intended to make consumers' daily use of products more practical, the ease of use perceptions are expected to have a positive effect on this process. Thus, the research hypotheses were developed as follows:

$H_{1 a}$ : The effect of consumers' perceived usefulness from a product on their attitudes toward the product differs according to product design.

$H_{1 b}$ : The effect of consumers' perceived usefulness from a product on their attitudes toward the product differs according to product type.

$H_{2 a}$ : The effect of consumers' perceived ease of use from a product on their attitudes toward the product differs according to product design.

$H_{2 b}$ : The effect of consumers' perceived ease of use from a product on their attitudes toward the product differs according to product type.

Perceived usefulness includes beliefs that individuals can see what is important in determining what is important when they want or refuse to use a technological product, and what kind of usefulness they will see when using an existing product, so that they can get help from the relevant product in order to do better in carrying out their business and activities (Davis, 1989). In TAM, while individuals generally use technological products, they believe that their performance will increase (Yücel and Gülbahar, 2013), and the easier it is to use the technology, the more positive the attitude and intention to use the technology is stated (Davis et al., 1989). In the studies conducted within the framework of TAM, the positive relationship between perceived usefulness and ease of use was supported (Childers et al., 2001; Lin et al., 2007; Venkatesh, 1999). In a study conducted on the use of a website, it was found that the easier the learning, using, or navigating, the easier it was to perceive a business/brand compared to its competitors and the higher the perception of the usefulness of the user (Lavie and Tractinsky, 2004).

In the context of this study, perceived usefulness can be defined as the degree to which individuals believe that the technological attribute used in products in the use of durable consumer goods will facilitate individuals to perform their jobs. The effect of perceived usefulness on acceptance and intention to adopt has been confirmed by many studies in this field (Davis, 1989; Kim et al., 2015; Wang et al., 2014; Venkatesh and Davis, 2000). Thus, the research hypothesis was developed as follows:

$H_{3 a}$ : The effect of consumers' perceived ease of use from a product on their perceived usefulness toward the product differs according to product design.

$H_{3 b}$ : The effect of consumers' perceived ease of use from a product on their perceived usefulness toward the product differs according to product type.

Attitude is defined as a positive or negative evaluation response to something or someone. (Davis, 1989). An attitude towards a behavior indicates which person evaluates his / her behavior negatively or positively. According to Davis's research (1989), consumer's intention to use an information system affects attitudes towards usage behavior. As a result of the studies 
conducted, it was seen that when an individual had a positive attitude, the purchase intention was converted into behavior. In addition to these studies, it has been stated that product design features do not have a direct effect on attitudes and behaviors, but design features indirectly affect attitudes and behaviors through perceived usefulness and perceived ease of use (Davis, 1989).

$H_{4 a}$ : The effect of consumers' attitudes toward a product on their behavioral intentions towards product differs according to product design.

$H_{4 b}$ : The effect of consumers' attitudes toward a product on their behavioral intentions towards product differs according to product type.

\section{Method}

This study aims to determine the differences in effects between perceived usefulness, perceived ease of use, attitude towards products, and behavioral intention, which have been constituted by the use of technological attributes in product design in the frame of TAM. Another aim of this study is to examine whether these effects differ according to product type or not.

\section{Figure 1 Research Model}

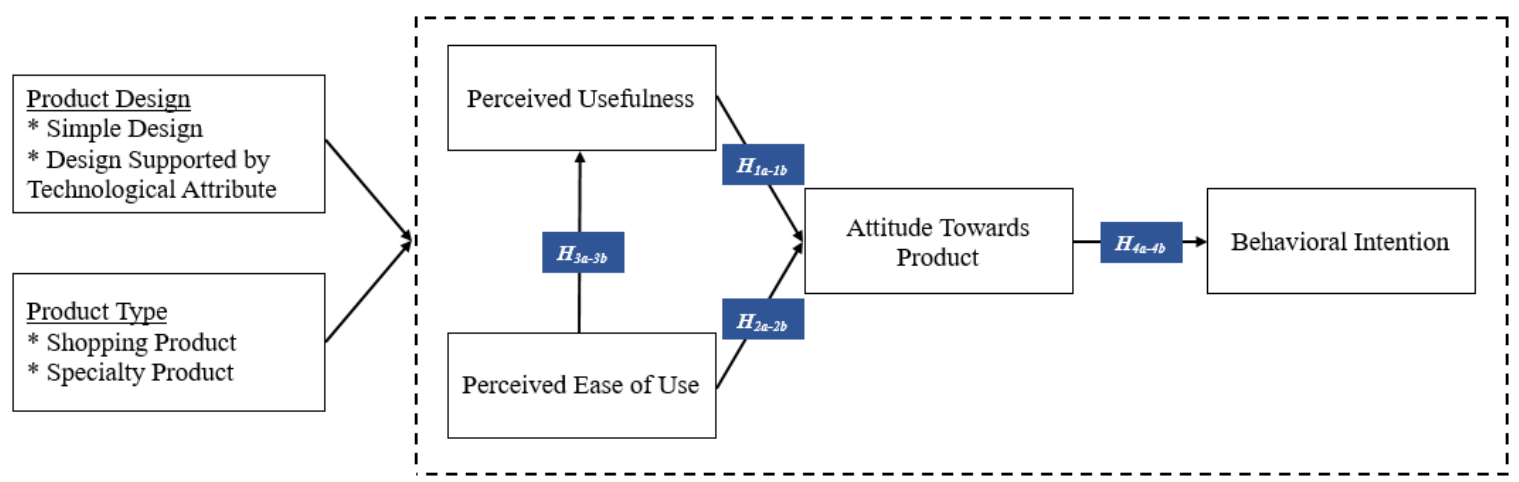

The items were rated on 5 points interval scale ranged from 1 (strongly disagree) to 5 (strongly agree). The Perceived usefulness variable was measured with six items that were adapted from Davis (1985). Perceived ease of use variable was measured with seven items that were adapted from Davis (1985). Attitude towards product variable was measured with four items that were adapted from Ajzen et al. (2004). Behavioral intention variable was measured with six items that were adapted from Dodds et al. (1991).

\section{Experimental Design of the Study}

This study examines the causality between the variables by adopting the experimental design approach (Hair et al., 2010; Malhotra, 2010). According to that, a research design was formed using the scenario technique and between-subjects design to reach research objectives. Product design and product type variables were identified as experiment variables in this study. With regard to these variables, four different experimental groups were constituted to evaluate experiment variables' effects. This study was based on a 2 (Product Design: Simple Design vs. Design Supported by Technological Attribute) x 2 (Product Type: Shopping Product vs. Specialty Product) factorial between-subject design. 
Figure 2 Product images that have been encountered by the participants assigned to experimental groups

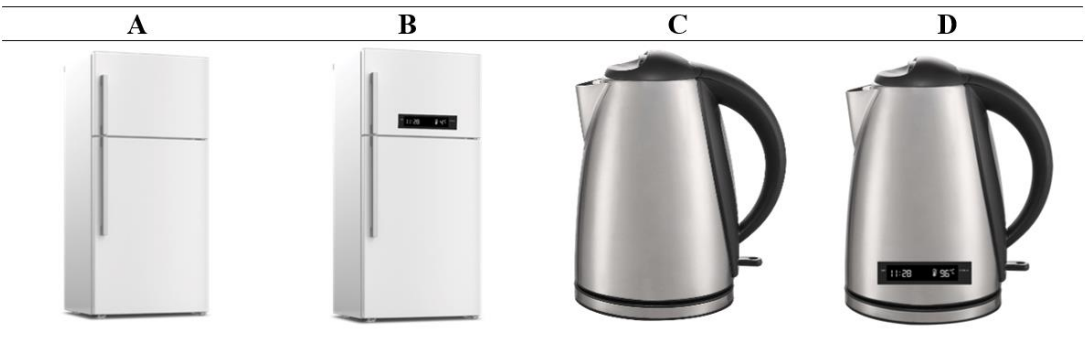

The panels showing the time and temperature were used to create the design supported by technological attribute in the product design variable, which is one of the experiment variables for the products. The panels are as shown in Figure 3.

Figure 3 The Panel Used to Create the Design Supported by Technological Attribute

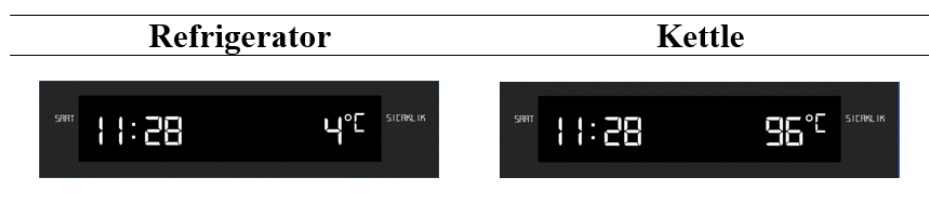

The measurement performed according to the between-subject design is a post-test without a control group depending upon scenarios.

In the preparation process of the scenarios for the products, the product features were searched from open sources on the internet and the recommendations of the users of the products in various forums were examined, and the factors which consumers take into consideration when purchasing the products within the scope of the research were determined.

\section{Selection of the Product Type}

Products are classified based on durability (durable, nondurable), tangibility, and use of the consumer (convenience, shopping, specialty) (Kotler and Keller, 2012). Depending on this classification, durable consumer products and shopping and specialty products were included in the scope of the research. According to the objective of the study, to create the design supported with a technological attribute, the product types were selected on which a technological attribute could be placed. Durable consumer goods are defined as tangible goods that can be used for a long time and not intended for single-use (Kotler and Keller, 2012). Convenience product type was not included in the study due to its low consumer involvement level and high purchasing frequency (Kavak and Sı ğınd1, 2012). Instead, shopping and specialty product types were included because of their low purchasing frequency and higher consumer involvement level characteristics (Kavak and Sı ğındı, 2012), which are compatible with durable consumer products.

According to the research model, it is expected that the interactions between the perceived usefulness, perceived ease of use, attitude towards product, and behavioral intentions of individuals regarding products will differ according to their simple design or design supported by a technological attribute. In order to examine these differences accurately, two products were identified as a refrigerator and kettle to represent specialty and shopping product types. When determining these products, durable consumer product groups suitable for household consumption were examined. 
Durable consumer goods suitable for household consumption are classified under three categories as large household appliances, small household appliances, and consumer electronics. The large household appliance sector is one of the leading sectors of Turkey's economy with its high added value, substantial export volumes, competitiveness, and highly recognized brands (TSKB, 2018). At the end of 2017, the production of large household appliances increased by $9 \%$ compared to the previous year and reached its historical peak. (TSKB, 2018). When the production amounts of the large household appliance sector are analyzed by product groups, washing machines and refrigerators are the product groups with the highest number of production (TSKB, 2018). In 2016, the small household appliance sector grew by $5 \%$ and reached a turnover of about 61 billion dollars. While various dynamics had a role in the 2016 sales performances in the advancement of technology and small household appliance sectors, innovative goods contributed to growth by supporting the sectors (GfK, 2017). Besides the fact that durable consumer goods groups suitable for household consumption are so important, it has found from the consumer's perspective that consumers not only buy such products because of the functional properties but also with the expectation of matching those products to the general concept of the kitchen. Because, in recent years, the kitchen has become like a living room where entertaining guests and socializing takes place, consumers have seen such products like refrigerator, oven, dishwasher, and kettle as a part of the kitchen. For this reason, the scope of the research is identified as durable consumer goods suitable for household consumption, and these products have been separated into specialty and shopping product groups.

\section{Sampling and Data Collection Process}

The population of the study consists of 25-64-year-old female consumers living in Istanbul who have bought at least one refrigerator or kettle in the last five years. Both academic studies and sector reports have shown that female consumers have an active role primarily in the food and cleaning categories and after these categories in the large household appliances and furniture sector (Kitapç1 and Dörtyol, 2009; Levy and Lee, 2002). Similarly, according to Özbek and Koç's (2009) study, women play a primary role in purchasing decisions about cleaning and kitchen products, carpets, and furniture. In another study, men play an important role in matters that influence the ultimate purchase decision such as the time of purchase or budget adjustment. It has been observed that women play an influential role in decisions such as the color or type of product to buy (Nanda et al. 2006). According to the literature and because the product types identified within the scope of the research as durable consumer products suitable for household consumption and the density of the end-users of these products consist of female consumers, the scope of the research is limited to female consumers. Also, considering that the average age at first marriage was 24.8 for women in 2018 (TÜIK, 2018) and that the elderly population has defined by the OECD as 65 years and over, it is deemed suitable to limit the population to 2564 age range.

In the study, it has been considered that access to the whole population cannot be possible due to the scattered structure, size, number of the population and the time, and financial constraints. In such cases where performing the full census is not possible, the sampling method is preferred to estimate the population (Malhotra, 2010). Consequently, the convenience sampling method was used in this study.

The sample size formula was used to calculate the appropriate number of samples for the study (Malhotra, 2010). The sample size has been determined as 504 by assigning 126 participants with similar socio-demographic characteristics to each experimental group, which has been planned according to the $2 \times 2$ between-subject design. The data were collected between May-June 2019, using face-to-face survey method. This method was preferred because this 
makes it possible to identify the participants' suitability to the experimental structure of the study and to control the involvement process of the participants.

\section{Manipulation Check}

Two questions have been addressed to the research participants to determine their awareness about the manipulations. For the product design's manipulation check: $\left(\mathrm{Q}_{1}\right)$ : "Is there any technological panel on the surface of the product in the image?". And for the product type's manipulation check: $\left(\mathrm{Q}_{2}\right)$ : "Does the product in the image cost a significant amount of money compared to other products in the durable consumer goods suitable for household consumption category?" questions have asked. In this study, durable consumer goods suitable for household consumption products have been separated into specialty and shopping product groups. Product classifications depend on the buyer's evaluation of price (Murphy and Enis, 1986). Specialty products are defined as products with high prices compared to others (Murphy and Enis, 1986); consumers are also willing to make special purchasing effort for them (Holton, 1958; Kotler and Armstrong, 2012; Luck, 1959). According to the literature, monetary value was used as a criterion for the specialty product type that differentiates it from shopping products.

Answers given by the participants in different experimental groups $\left(A_{1,2,3,4}\right)$ are shown in Table 1. According to the results, the use of the design supported by a technological attribute has been identified correctly by $98.8 \%$ of the participants, simple design has been identified correctly by $88.9 \%$, specialty product has been identified correctly by $95.2 \%$, and shopping product has been identified correctly by $82.9 \%$. According to the results, it has been determined that the manipulation is valid.

Table 1 Manipulation Check

\begin{tabular}{|c|c|c|c|c|}
\hline & \multicolumn{4}{|c|}{ Product Design $\left(n_{i}=252\right)$} \\
\hline & \multicolumn{2}{|c|}{$\begin{array}{l}Q_{1}: \text { Design Supported by } \\
\text { Technological Attribute }\end{array}$} & \multicolumn{2}{|c|}{$Q_{1}:$ Simple Design } \\
\hline & $n$ & $\%$ & $n$ & $\%$ \\
\hline $\begin{array}{l}A_{I}:(\text { Yes }) \text { Design Supported by } \\
\text { Technological Attribute }\end{array}$ & 249 & $98.80 \%$ & 28 & $11.10 \%$ \\
\hline \multirow{4}{*}{$A_{2}:(\mathrm{No})$ Simple Design } & 3 & $1.20 \%$ & 224 & $88.90 \%$ \\
\hline & \multicolumn{4}{|c|}{ Product Type $\left(n_{j}=252\right)$} \\
\hline & \multicolumn{2}{|c|}{$Q_{2}$. Specialty Product } & \multicolumn{2}{|c|}{$Q_{2}:$ Shopping Product } \\
\hline & $n$ & $\%$ & $n$ & $\%$ \\
\hline$A_{3}:$ (Yes) Specialty Product & 240 & $95.20 \%$ & 43 & $17.06 \%$ \\
\hline$A_{4}:$ (No) Shopping Product & 12 & $4.80 \%$ & 209 & $82.94 \%$ \\
\hline
\end{tabular}

\section{Analysis and Findings}

Demographic characteristics, the similarity of the experimental groups, and the validity and reliability of the research scales have been evaluated before testing the research hypotheses.

While assigning the participants to four different experimental groups that were designed based on the experimental structure of the research, creating a homogenous structure without intergroup differences was aimed. The chi-square test was applied to the data obtained to evaluate whether the structure was similar in terms of demographic characteristics of the experimental groups as designed. According to the results, it has been found that there is no statistically significant difference between experimental groups in terms of research participants' ages, marital status, educational status, occupations, and monthly household incomes. $\left[\chi^{2}\right.$ age $=9.569, p=.387 ; \chi^{2}$ marital status $=1.393, p=.707 ; \chi^{2}$ educational status $=$ $10.097, p=.814 ; \chi^{2}$ occupation $=20.355, p=.313 ; \chi^{2}$ monthly household income $=16.663, p$ 
$=.339]$. Therefore, it is evaluated that there is no difference between the experimental groups as designed previously and experimental groups are equivalent to each other. Besides, only women have been included in the research to ensure that the participants' level of product involvement is similar to the research products.

Table 2 Demographic Characteristics and Distributions in the Experimental Groups

\begin{tabular}{|c|c|c|c|c|c|c|c|c|c|}
\hline \multirow[t]{2}{*}{ Variable } & \multicolumn{2}{|c|}{$\begin{array}{c}\text { Total } \\
(n=504)\end{array}$} & \multicolumn{4}{|c|}{$\begin{array}{c}\text { Experimental Group } \\
\left(\mathrm{n}_{\mathrm{i}}=\mathbf{1 2 6}\right)\end{array}$} & \multicolumn{3}{|c|}{$\begin{array}{c}\text { Similarity Analysis of } \\
\text { the Experimental } \\
\text { Groups }\end{array}$} \\
\hline & $n$ & $\%$ & $A$ & $B$ & $C$ & $D$ & $\chi^{2}$ & $d f$ & $p$ \\
\hline Age & & & & & & & \multirow{5}{*}{9.569} & \multirow[t]{5}{*}{9} & \multirow[t]{5}{*}{.387} \\
\hline $25-34$ & 150 & 29.8 & 35 & 34 & 41 & 40 & & & \\
\hline $35-44$ & 143 & 28.4 & 38 & 34 & 37 & 34 & & & \\
\hline $45-54$ & 127 & 25.2 & 33 & 35 & 35 & 24 & & & \\
\hline $55-64$ & 84 & 16.7 & 20 & 23 & 13 & 28 & & & \\
\hline \multicolumn{7}{|l|}{ Marital Status } & \multirow[t]{3}{*}{1.393} & \multirow[t]{3}{*}{3} & \multirow[t]{3}{*}{.707} \\
\hline Single & 137 & 27.2 & 37 & 33 & 30 & 37 & & & \\
\hline Married & 367 & 72.8 & 89 & 93 & 96 & 89 & & & \\
\hline \multicolumn{7}{|l|}{ Educational Status } & \multirow[t]{7}{*}{10.097} & \multirow[t]{7}{*}{15} & \multirow[t]{7}{*}{.814} \\
\hline Elementary School & 108 & 21.4 & 21 & 30 & 26 & 31 & & & \\
\hline Secondary School & 60 & 11.9 & 17 & 17 & 13 & 13 & & & \\
\hline High School & 147 & 29.2 & 33 & 34 & 43 & 37 & & & \\
\hline Associate Degree & 47 & 9.3 & 12 & 11 & 14 & 10 & & & \\
\hline Undergraduate & 121 & 24.0 & 38 & 28 & 27 & 28 & & & \\
\hline Postgraduate & 21 & 4.2 & 5 & 6 & 3 & 7 & & & \\
\hline \multicolumn{7}{|l|}{ Occupation } & \multirow[t]{8}{*}{20.355} & \multirow[t]{8}{*}{18} & \multirow[t]{8}{*}{.313} \\
\hline Private Sector Employee & 140 & 27.8 & 40 & 32 & 35 & 33 & & & \\
\hline Public Sector Employee & 62 & 12.3 & 13 & 19 & 12 & 18 & & & \\
\hline Self -Employed & 30 & 6.0 & 11 & 8 & 8 & 3 & & & \\
\hline Retired & 25 & 5.0 & 6 & 5 & 3 & 11 & & & \\
\hline Housewife & 198 & 39.3 & 45 & 54 & 51 & 48 & & & \\
\hline Student & 25 & 5.0 & 8 & 3 & 8 & 6 & & & \\
\hline Other & 24 & 4.0 & 3 & 5 & 9 & 7 & & & \\
\hline \multicolumn{7}{|l|}{ Monthly Household Income } & \multirow[t]{7}{*}{16.663} & \multirow[t]{7}{*}{15} & \multirow[t]{7}{*}{.339} \\
\hline $2000 €$ and less & 65 & 12.9 & 21 & 15 & 7 & 22 & & & \\
\hline $2001-4000 €$ & 201 & 39.9 & 46 & 48 & 58 & 49 & & & \\
\hline 4001-6000 ま & 138 & 27.4 & 33 & 35 & 41 & 29 & & & \\
\hline 6001-8000 € & 45 & 8.9 & 12 & 13 & 9 & 11 & & & \\
\hline 8001-10000 も & 25 & 5.0 & 8 & 5 & 4 & 8 & & & \\
\hline $10001 €$ or above & 30 & 6.0 & 6 & 10 & 7 & 7 & & & \\
\hline
\end{tabular}

To determine whether the technological attributes make sense to the consumer or not, the following questions have been asked to the participants: $\left(\mathrm{Q}_{3}\right)$ Do you think that use of technological attributes in refrigerator/kettle design will benefit you? $\left(\mathrm{Q}_{4}\right)$ Is the use of technological attributes in refrigerator/kettle design important in your purchasing decision? (Q5) How important is the use of technological attributes in refrigerator/kettle design for you? These questions were directed to the participants after completing the questionnaire to prevent response bias. The questions were rated on an interval scale ranged from 1 to 5 . The percentage of participants who scored the scale midpoint and above are $85.3 \%, 78.5 \%$, and $80.6 \%$, respectively. It has been concluded that technological attributes in product design make sense for a considerable majority of the participants.

\section{Validity and Reliability Analyses}

To test the validity and reliability of the research scales, exploratory factor analysis has been applied, and Cronbach's Alpha coefficient was calculated. "BI2" coded item was excluded from 
the analysis due to its low factor load and negative effect on the reliability level. Factor structures, percentage of explained variance and Cronbach's Alpha coefficients obtained as a result of the analyses are given in Table 3. Accordingly, it has found that the percentage of explained variances of the research variables were above acceptable values (.60 and above) and their structures were consistent with the literature. Also, it has seen that the variables have highreliability values.

Table 3 Results of the Validity and Reliability Analyses

\begin{tabular}{|c|c|c|c|c|}
\hline Code & Item & $\begin{array}{l}\text { Factor } \\
\text { Loadings }\end{array}$ & $\begin{array}{l}\text { Percentage } \\
\text { of } \\
\text { explained } \\
\text { variance }\end{array}$ & $\begin{array}{l}\text { Cronbach's } \\
\text { Alpha }\end{array}$ \\
\hline \multicolumn{2}{|c|}{ Perceived Usefulness } & & \multirow[t]{7}{*}{$65.11 \%$} & \multirow[t]{7}{*}{.892} \\
\hline PU3 & $\begin{array}{l}\text { Using this product enhances my performance in the } \\
\text { kitchen. }\end{array}$ & .879 & & \\
\hline PU2 & $\begin{array}{l}\text { Using this product allows me to do my kitchen work } \\
\text { more quickly. }\end{array}$ & .856 & & \\
\hline PU6 & Using this product makes my kitchen work easier. & .826 & & \\
\hline PU4 & Using this product enhances my productivity. & .778 & & \\
\hline PU5 & $\begin{array}{l}\text { Using this product improves my efficiency in the } \\
\text { kitchen. }\end{array}$ & .757 & & \\
\hline PU1 & I find this product useful for my life in general. & .735 & & \\
\hline \multicolumn{2}{|c|}{ Perceived Ease of Use } & & \multirow[t]{8}{*}{$65.55 \%$} & \multirow[t]{8}{*}{.907} \\
\hline PEU5 & The use of this product is understandable. & .907 & & \\
\hline PEU4 & The use of this product is clear. & .902 & & \\
\hline PEU6 & The use of this product is easy. & .902 & & \\
\hline PEU3 & Using this product will not require much mental effort. & .815 & & \\
\hline PEU1 & It is easy for me to learn how to use this product. & .802 & & \\
\hline PEU7 & $\begin{array}{l}\text { By purchasing this product. it will be easy to do what I } \\
\text { want to do. }\end{array}$ & .651 & & \\
\hline PEU2 & $\begin{array}{l}\text { By using this product. I can simply do what I want to } \\
\text { do. }\end{array}$ & .638 & & \\
\hline \multicolumn{2}{|c|}{ Attitude Towards the Product } & & \multirow[t]{5}{*}{$76.82 \%$} & \multirow[t]{5}{*}{.898} \\
\hline ATP3 & It is sensible to use this product. & .907 & & \\
\hline ATP4 & It is pleasurable to use this product. & .873 & & \\
\hline ATP2 & It is important to use this product. & .863 & & \\
\hline ATP1 & It is a good idea to use this product. & .861 & & \\
\hline \multicolumn{2}{|c|}{ Behavioral Intention } & & \multirow[t]{6}{*}{$69.78 \%$} & \multirow[t]{6}{*}{.891} \\
\hline BI6 & I want to buy this product. & .867 & & \\
\hline BI4 & I have a desire to buy this product. & .863 & & \\
\hline $\mathrm{BI} 3$ & Most probably I will buy this product. & .851 & & \\
\hline BI5 & $\begin{array}{l}\text { If I were to buy a product. I would most probably buy } \\
\text { this product in the image. }\end{array}$ & .823 & & \\
\hline BI1 & There is a possibility that I purchase this product. & .769 & & \\
\hline
\end{tabular}

* "Product" refers to a refrigerator or kettle that differ according to the experimental groups.

\section{MANOVA Analysis}

MANOVA analysis was conducted to test whether the effect of perceived usefulness and perceived ease of use on the attitude towards product and behavioral intention differ or not according to the use of simple design or design supported by technological attribute in the product. Besides, MANOVA analysis is also performed to test whether these effects differ 
according to the type of product (specialty or shopping). Analysis results are shown in Table 4. According to the results, it has been found that the effects of experiment variables (product design and product type) on research variables are statistically significant $(p<.05)$. However, the interaction between these two experiment variables does not have a statistically significant effect on the research variables $(p>.05)$.

When the evaluation of whether the differences of each dependent variable constituted by the statistically significant effects are significant or not, it was found that the product design has statistically significant differences in perceived usefulness $\left(F_{1}(1,500)=5.425\right)$, attitude towards product $\left(F_{3}(1,500)=3.935\right)$ and behavioral intention $\left(F_{4}(1,500)=13.092\right)$. Besides, the product type has statistically significant differences in perceived usefulness $\left(F_{1}(1,500)=\right.$ $12.458)$, perceived ease of use $\left(F_{2}(1,500)=4.899\right)$ and behavioral intention $\left(F_{4}(1,500)=\right.$ 5.348).

When the results of the MANOVA analysis is examined, for the product design variable (simple design vs. design supported by technological attribute), there are statistically significant differences in the means for perceived usefulness $\left(F_{1}(1,500)=5.425\right)$, attitude towards product $\left(F_{3}(1,500)=3.935\right)$ and behavioral intention $\left(F_{4}(1,500)=13.092\right)$. Besides, for the product type variable (shopping product vs. specialty product) there are statistically significant differences in the means for perceived usefulness $\left(F_{1}(1,500)=12.458\right)$, perceived ease of use $\left(F_{2}(1,500)=4.899\right)$ and behavioral intention $\left(F_{4}(1,500)=5.348\right)$.

Table 4 MANOVA Analysis Results

\begin{tabular}{|l|c|c|c|c|c|c|}
\hline & \multicolumn{2}{|c|}{ Multivariate Tests } & \multicolumn{4}{c|}{ Tests of Between-Subjects Effects } \\
\hline Effects & Wilks' 1 & $F(4,497)$ & $\boldsymbol{P U}$ & $\boldsymbol{P E U}$ & $\boldsymbol{A T P}$ & $\boldsymbol{B I}$ \\
\cline { 4 - 7 } & & & $F_{1}(1,500)$ & $F_{2}(1,500)$ & $F_{3}(1,500)$ & $F_{4}(1,500)$ \\
\hline Simple Main-Effects & & & & & & \\
\hline Product Design (PD) & .972 & $3.634^{*}$ & $5.425^{*}$ & 1.364 & $3.935^{*}$ & $13.092^{*}$ \\
\hline Product Type (PT) & .931 & $9.190^{*}$ & $12.458^{*}$ & $4.899^{*}$ & .370 & $5.348^{*}$ \\
\hline Interaction Effects & & & & & & .003 \\
\hline PD x PT & .997 & .347 & .416 & .042 & .762 & .003 \\
\hline
\end{tabular}

Figure 4 and Figure 5 show statistically significant differences in the means for the dependent variables between groups of the product design and the product type variables as a result of the MANOVA analysis.

Figure 4 Variation of the Means of Dependent Variables According to Product Design

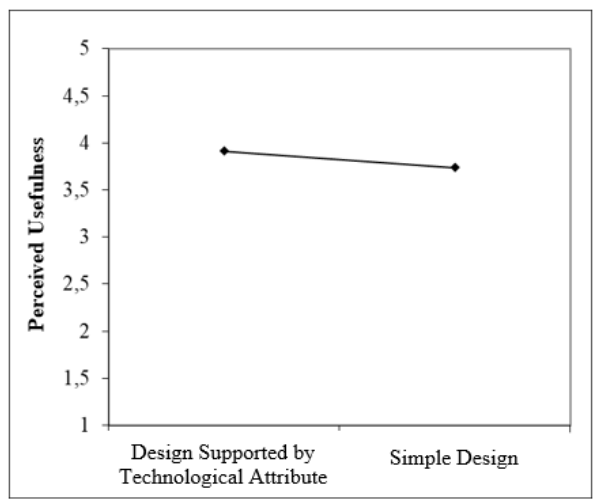


According to the means for perceived usefulness $\left(\bar{X}_{\text {design supported by tech. }}=3.91 ; \bar{X}_{\text {simple }}\right.$ design $=3.74)$, attitude towards product $\left(\bar{X}_{\text {design supported by tech. }}=3.94 ; \bar{X}_{\text {simple design }}=3.79\right)$ and behavioral intention $\left(\bar{X}_{\text {design supported by tech. }}=3.56 ; \bar{X}_{\text {simple design }}=3.30\right)$, the group that encountered the product image and scenario with the design supported by technological attributes had a higher value than the group that encountered the product image and scenario with simple design.

Figure 5 Variation of the Means of Dependent Variables According to Product Type

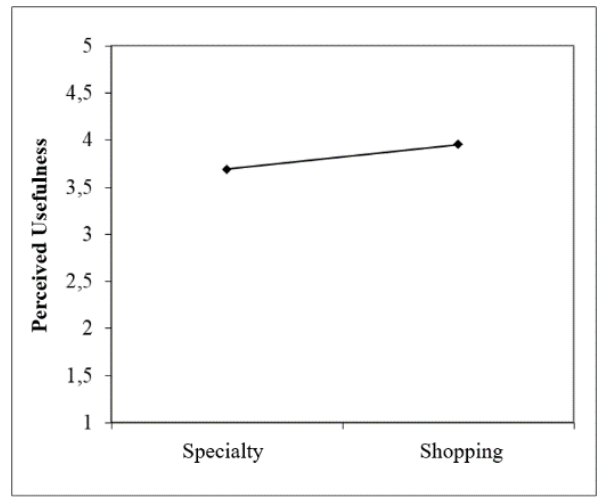

According to the means for perceived usefulness $\left(\bar{X}_{\text {shopping }}=3.96 ; \bar{X}_{\text {specialty }}=3.70\right)$, perceived ease of use $\left(\bar{X}_{\text {shopping }}=4.22 ; \bar{X}_{\text {specialty }}=4.07\right)$, and behavioral intention $\left(\bar{X}_{\text {shopping }}=3.51\right.$; $\left.\bar{X}_{\text {specialty }}=3.35\right)$, the group that encountered the shopping product had a higher value than the group that encountered the specialty product.

\section{Structural Equation Modeling}

In order to evaluate the interactions of the dependent variables within the framework of TAM and to determine differences in the research model according to the experimental variables, multi-group structural equation modeling analysis was conducted. While conducting this analysis, firstly, a general structural model was created, and the differences of the valid model structure were evaluated at the group level. For the evaluation of group differences, the experimental variable structure is used, which has previously shown statistically significant effects determined in MANOVA analysis. Accordingly, product design and product type variables were independently subjected to group analysis. Since it was determined that the interactions between these variables were not statistically significant in the MANOVA analysis, the interaction effects were not included in the group analysis.

In the Structural Equation Modeling analysis, a measurement model was first created and tested with confirmatory factor analysis. Afterward, the structural model was formed based on the measurement model, which was considered valid and tested with path analysis.

Measurement Model: Convergent validity and discriminant validity evaluations were applied for the validity and reliability of the measurement model. AVE (average variance extracted) and CR (composite reliability) values were calculated to assess convergent validity. For the convergent validity, CR values are expected to be at least .70, and AVE values should be .50 and above (Fornell and Larcker, 1981). For the discriminant validity, the correlation matrix showing the relationships between the latent variables in the model was created, and the square root of the AVE value of each latent variable was calculated. Each variables' square root of AVE value should be greater than inter-variable correlation values for the discriminant validity (Fornell and Larcker, 1981). 
Results of the confirmatory factor analysis for the measurement model, AVE, and CR values are shown in Table 5.

Table 5 Measurement Model - Confirmatory Factor Analysis Results

\begin{tabular}{|c|c|c|c|c|}
\hline Variable & Item & Factor Loadings & AVE & CR \\
\hline \multirow{4}{*}{ Perceived Usefulness } & PU2 & .855 & \multirow{4}{*}{.673} & \multirow[t]{4}{*}{.891} \\
\hline & PU3 & .894 & & \\
\hline & PU4 & .734 & & \\
\hline & PU6 & .788 & & \\
\hline \multirow[t]{4}{*}{ Perceived Ease of Use } & PEU6 & .922 & \multirow[t]{4}{*}{.806} & \multirow[t]{4}{*}{.943} \\
\hline & PEU5 & .964 & & \\
\hline & PEU4 & .935 & & \\
\hline & PEU3 & .755 & & \\
\hline \multirow[t]{4}{*}{ Attitude Towards Product } & ATP4 & .886 & \multirow[t]{4}{*}{.757} & \multirow[t]{4}{*}{.926} \\
\hline & ATP3 & .911 & & \\
\hline & ATP2 & .829 & & \\
\hline & ATP1 & .853 & & \\
\hline \multirow[t]{4}{*}{ Behavioral Intention } & BI6 & .938 & \multirow[t]{4}{*}{.677} & \multirow[t]{4}{*}{.893} \\
\hline & BI5 & .862 & & \\
\hline & BI4 & .761 & & \\
\hline & BI3 & .713 & & \\
\hline
\end{tabular}

When deciding the final version of the measurement model, PEU1, PEU2, PEU7, PU1, PU5, BI1 coded items were excluded from the analysis due to their negative effects on the measurement model structure and model fit values.

The correlation matrix of the variables in the final measurement model and the square roots of AVE values are given in Table 6. When the values in Table 6 are examined, it is seen that there is no multicollinearity problem between the variables, and there is no evidence against discriminant validity.

Table 6 Correlation Matrix and Discriminant Validity Evaluations

\begin{tabular}{|l|c|c|c|c|}
\hline & PU & PEU & ATP & BI \\
\hline PU & $\mathbf{. 8 2 0}$ & & & \\
\hline PEU & .475 & .898 & & \\
\hline ATP & .666 & .653 & $\mathbf{. 8 7 0}$ & \\
\hline BI & .442 & .298 & .539 & $\mathbf{. 8 2 3}$ \\
\hline
\end{tabular}

* Diagonals represent the square root of AVE values.

Model fit values for the measurement model are given in Table 7. By taking as a reference to the approach of $\mathrm{Hu}$ and Bentler (1999), acceptable model fit values are evaluated as $\chi^{2} / s d$ $<=5, C F I>.90, S R M R<.10$, RMSEA <.08. Accordingly, the model fit values of the measurement model were within acceptable limits. 
Table $7 \quad$ Model Fit Values Calculated for the Measurement Model

\begin{tabular}{|l|c|c|c|c|c|c|}
\hline & $\chi^{\mathbf{2}}$ & sd & $\chi^{\mathbf{2}} / \mathbf{s d}$ & CFI & SRMR & RMSEA \\
\hline & 318.293 & 99 & 3.215 & .964 & .071 & .066 \\
\hline Good Model Fit* & & & $\leq \mathbf{3}$ & $\geq . \mathbf{9 5}$ & $\leq .08$ & $\leq . \mathbf{0 6}$ \\
\hline Acceptable Model Fit* & & & $\leq \mathbf{4 - 5}$ & $\geq . \mathbf{9 0}$ & $\leq . \mathbf{. 1 0}$ & $\leq . \mathbf{0 8}$ \\
\hline
\end{tabular}

As seen in Table 5, Table 6, and Table 7, standardized factor loads, AVE and CR values, correlation values, square roots of AVE values, and model fit values calculated for latent variable structures in the measurement model were acceptable. Therefore, it has been evaluated that the final measurement model structure is valid and can be used as the basis for the structural model test.

Structural Model: The structural model based on the final version of the measurement model was tested by path analysis. In path analysis, $t$ values that are not between \pm 1.96 were evaluated as statistically significant within a $95 \%$ confidence interval. Accordingly, when the findings in Table 8 were examined, it is seen that all structural relationships in the structural model of the research are significant.

Table $8 \quad$ Results of the Structural Model (Full Model)

\begin{tabular}{|l|l|l|l|l|l|l|c|}
\hline $\begin{array}{c}\text { Independent } \\
\text { Variable }\end{array}$ & & $\begin{array}{c}\text { Dependent } \\
\text { Variable }\end{array}$ & $\begin{array}{c}\text { Std. } \\
\text { Beta }\end{array}$ & b & S.E. & t & p \\
\hline PEU & $->$ & PU & .411 & .369 & .044 & 8.396 & $.000^{*}$ \\
\hline PEU & $->$ & ATP & .416 & .327 & .034 & 9.610 & $.000^{*}$ \\
\hline PU & $->$ & ATP & .442 & .386 & .039 & 9.874 & $.000^{*}$ \\
\hline ATP & $->$ & BI & .464 & .528 & .054 & 9.825 & $.000^{*}$ \\
\hline
\end{tabular}

As seen in Table 9, the model fit values for the structural model indicates an acceptable model fit.

Table 9 Model Fit Values Calculated for Structural Model

\begin{tabular}{|c|c|c|c|c|c|}
\hline$\chi^{\mathbf{2}}$ & sd & $\chi^{\mathbf{2} / \mathbf{s d}}$ & CFI & SRMR & RMSEA \\
\hline 294.151 & 99 & 2.971 & .968 & .062 & .063 \\
\hline
\end{tabular}

Multi-Group Analysis: According to the purpose of the study, all model tests related to the structural model, as well as multi-group analysis in structural equation modeling were performed. Therefore, the multi-group analysis was applied by taking into consideration the groups of the experimental variables (product design and product type).

In terms of the groups of product design variable, design supported by a technological attribute $\left(n_{1}=252\right)$, and simple design $\left(n_{2}=252\right)$, multi-group analysis was conducted, and analysis results are given in Table 10. When the effects in the structural model in terms of the design supported by a technological attribute have been examined, it has been found that the effects previously determined to be statistically significant in the whole model were similarly significant $(p<.05)$. Likewise, in terms of the simple design group, the effects were statistically significant in the whole model $(p<.05)$. 
Table $10 \quad$ Structural Model Results (Multi-Group Analysis - Product Design)

\begin{tabular}{|c|c|c|c|c|c|c|c|c|c|c|c|c|c|}
\hline & & & \multicolumn{5}{|c|}{$\begin{array}{c}\text { Design Supported by } \\
\text { Technological Attribute }\end{array}$} & \multicolumn{5}{|c|}{ Simple Design } & \multirow{2}{*}{$\begin{array}{c}Z \\
\text { Test }\end{array}$} \\
\hline $\begin{array}{l}\text { Independent } \\
\text { Variables }\end{array}$ & & $\begin{array}{c}\text { Dependent } \\
\text { Variables }\end{array}$ & $\begin{array}{l}\text { Std. } \\
\text { Beta }\end{array}$ & b & S.E. & $\mathbf{t}$ & $\mathbf{P}$ & $\begin{array}{l}\text { Std. } \\
\text { Beta }\end{array}$ & b & S.E. & $\mathbf{t}$ & $\mathbf{P}$ & \\
\hline PEU & -> & PU & .271 & .230 & .059 & 3.936 & .000 & .514 & .598 & .080 & 7.439 & .000 & -3.70 \\
\hline PEU & -> & ATP & .354 & .256 & .043 & 5.957 & .000 & .498 & .411 & 053 & 7.770 & .000 & -2.27 \\
\hline PU & -> & ATP & .506 & .430 & .055 & 7.795 & .000 & .355 & .251 & .044 & 5.701 & .000 & 2.54 \\
\hline ATP & $\rightarrow$ & BI & .507 & .629 & .084 & 7.508 & .000 & .413 & .423 & .069 & 6.150 & .000 & 1.90 \\
\hline
\end{tabular}

The z-test was conducted to assess whether the effects differ or not between each group of the product design variable. As a result of the z-test conducted for pairwise comparison, $\mathrm{z}$ values have been calculated for each structural equation in the model. Z-values were not between \pm 1.96 and evaluated as statistically significant within a $95 \%$ confidence interval. Accordingly, the effect of perceived ease of use on perceived usefulness, the effect of perceived ease of use on attitude towards the product, and the effect of perceived usefulness on attitude towards the product have a statistically significant difference between the groups in terms of product design. As a result, $\mathrm{H}_{1 \mathrm{a}}, \mathrm{H}_{2 \mathrm{a}}, \mathrm{H}_{3 \mathrm{a}}$ hypotheses are supported, while $\mathrm{H}_{4 \mathrm{a}}$ is not supported.

When the differences of effects are evaluated in terms of product design groups, it has been found that the effect of perceived ease of use on perceived usefulness was higher in the simple design group $(\beta=.514)$ than the design supported by technological attribute group $(\beta=.271)$. Similarly, it was determined that the effect of perceived ease of use on attitude towards the product was higher in the simple design group $(\beta=.498)$ than the design supported by the technological attribute group $(\beta=.354)$. However, the effect of the perceived usefulness on attitude towards the product was higher in the design supported by the technological attribute group $(\beta=.506)$ than the simple design group $(\beta=.355)$.

Table 11 Structural Model Results (Multi-Group Analysis - Product Type)

\begin{tabular}{|c|c|c|c|c|c|c|c|c|c|c|c|c|c|}
\hline & & & \multicolumn{4}{|c|}{ Specialty Product } & \multicolumn{5}{|c|}{ Shopping Product } & \multirow{2}{Z}{ Z } \\
\cline { 1 - 2 } $\begin{array}{c}\text { Independent } \\
\text { Variable }\end{array}$ & & $\begin{array}{c}\text { Dependent } \\
\text { Variable }\end{array}$ & $\begin{array}{c}\text { Std. } \\
\text { Beta }\end{array}$ & $\mathbf{b}$ & S.E. & $\mathbf{t}$ & $\mathbf{P}$ & $\begin{array}{c}\text { Std. } \\
\text { Beta }\end{array}$ & $\mathbf{b}$ & S.E. & $\mathbf{t}$ & $\mathbf{P}$ & Test \\
\hline PEU & $->$ & PU & .364 & .319 & .061 & 5.276 & .000 & .478 & .446 & .065 & 6.827 & .000 & -1.42 \\
\hline PEU & $->$ & ATP & .458 & .373 & .050 & 7.493 & .000 & .324 & .242 & .045 & 5.381 & .000 & 1.95 \\
\hline PU & $->$ & ATP & .397 & .368 & .057 & 6.478 & .000 & .553 & .443 & .054 & 8.271 & .000 & -.96 \\
\hline ATP & $->$ & BI & .430 & .490 & .076 & 6.409 & .000 & .485 & .555 & .076 & 7.308 & .000 & -.60 \\
\hline
\end{tabular}

In terms of the groups of the product type variable, specialty product $\left(n_{1}=252\right)$, and shopping product $\left(n_{2}=252\right)$, multi-group analysis was conducted and the analysis results are given in Table 11. The effects were examined in the structural model in terms of the specialty product group and it has been found that the effects previously determined to be statistically significant in the whole model were similarly significant $(p<.05)$. Likewise, in terms of the shopping product group, the effects were statistically significant in the whole model $(p<.05)$.

The z-test was conducted to assess whether the effects differ or not between each group of the product type variable. However, a value outside the $\mathrm{z}$ value \pm 1.96 was not calculated within the $95 \%$ confidence level. Accordingly, it has been found that the differences in effects between groups of the product type were not statistically significant. Therefore, the structural 
model does not differ according to the product type variable, and the whole model is still valid. In conclusion, $\mathrm{H}_{1 \mathrm{~b}}, \mathrm{H}_{2 \mathrm{~b}}, \mathrm{H}_{3 \mathrm{~b}}, \mathrm{H}_{4 \mathrm{~b}}$ hypotheses were not supported.

\section{Conclusion and Discussion}

As a result of the study, it has been found that the product design and product type have effects on consumers' perceived usefulness, perceived ease of use, attitude towards product, and behavioral intention independently. The interaction effect of product design and product type was not statistically significant; therefore, it has been found that the product design is an important feature that makes a difference in consumers' technological product acceptance process regardless of product type. Besides, when a technological attribute is used in product design, consumers perceive more usefulness, develop a more positive attitude towards the product, and their behavioral intentions become more positive. These findings are consistent with the findings of the other studies in the literature (Arora and Arora, 2017; Goldenberg et al., 1999; Moreau et al., 2001; Rindova and Petkova, 2007; Talke et al., 2009;) about consumer evaluation of product designs, the level of innovation in design, and product and design congruity. The attributes used in design affect perceived usefulness, value perceptions, and attitudes of the consumers positively. Also, it has been determined that whether the product is a specialty product or shopping product is distinctive. When consumers perceive more usefulness and ease of use from shopping products, their behavioral intention towards them becomes more positive.

The model proposed in this study was found to be significant and valid, supporting the relationships between variables in TAM (Childers et al., 2001; Dabholkar and Bagozzi, 2002; Davis et al., 1989; Gentry and Colantone, 2002; Kulviwat et al., 2007; Lavie and Tractinsky, 2004; Van der Heijden, 2003; Yücel and Gülbahar, 2013). In the framework of the model, it was found that perceived ease of use had a positive effect on perceived usefulness and attitude towards the product, perceived usefulness had a positive effect on attitude towards the product, and attitude towards product had a positive effect on behavioral intention. Additionally, it was found that the model differs according to the product design, but it shows no difference in terms of the product type, and the model is valid for all product types.

When technological attributes are used in product design, the effect of consumers' perceived ease of use on perceived usefulness and their attitude towards the product is lower compared to the usage of simple design. Our findings demonstrate that if a technological attribute is used in the product's design, the perceived ease of use is less important in terms of consumers' perceived usefulness and positive attitudes towards the product compared to the simple design. When the simple design is used in the product design, perceived ease of use is more decisive for consumers to perceive more usefulness and develop more positive attitudes towards the product. Similar results can be found in the study of Creusen and Schoormans (2005), which shows that if the visual design complexity of the product is low, the perception of ease of use is high in products. Likewise, Cyr et al. (2006) have found that design complexity has negative effects on consumers' perception of ease of use. In conclusion, if a simple design is used in a product design, adding some features which make consumers perceive more ease of use from the product can be recommended to marketers. On the other hand, if a technological attribute is used in the product's design, in order to ensure consumers perceive more usefulness and develop more positive attitudes towards the product, adding only some features which make consumers perceive more ease of use from the product is insufficient.

When a technological attribute is used in product design, the effect of consumers' perceived usefulness on their attitude towards the product is higher compared to the usage of simple design. Therefore, when a technological attribute is used in the product design, perceived 
usefulness is more decisive for consumers to develop more positive attitudes towards the product. The perceived usefulness, which has been defined as a degree that individuals believe the technological attribute used in the products will provide convenience for the consumers to perform their work in the use of durable consumer goods, is higher in the products that have been designed with technological attributes. This result is consistent with the studies of Venkatesh and Davis (2000), Wang et al. (2014), Kim et al. (2015). In conclusion, a product that is designed with technological attributes, giving importance to features that lead consumers to perceive usefulness from the product, can be recommended to marketers.

\section{Limitations and Further Research}

This study has several limitations that can suggest opportunities for future research. Product type, which is one of the experimental variables, is limited to shopping and specialty products, and the selection of refrigerator and kettle products to represent these product types constitute the most important limitation of this research. Besides, some limitations are arising from the convenience sampling method and the approach of assigning participants to experimental groups. Additional research in different samples and product types would enhance the generalizability of these findings. The use of a panel to create the design supported by a technological attribute is another limitation of this study. Constructing different designs to represent the technological attribute may enhance the validity of the research findings. Using technological attributes in different technological innovation levels by designing them with radical or incremental changes is also recommended for further studies. 


\section{References}

Ajzen, I., Brown, T. C. and Carvajal, F. (2004). "Explaining the Discrepancy Between Intentions and Actions: The Case of Hypothetical Bias in Contingent Valuation," Society for Personality and Social Psychology, 30(9): 1108-1121.

Alessi, A. (2000). The Dream Factory. Milan: Electa-Alessi.

Anderson, P., and Tushman, M. L. (1990). "Technological Discontinuities and Dominant Designs: A Cyclical Model of Technological Change," Administrative Science Quarterly, 35(4): 604-633.

Arora, S. A. and Arora, A. (2017). "WYSIWYG-Seeing is Believing: Consumer Responses to Levels of Design Newness, Product Innovativeness, and the Role of Country-ofOrigin," Journal of International Consumer Marketing, 29(3):135-161.

Benner, M. J., and Tushman, M. L. (2003). "Exploitation, Exploration, and Process Management: The Productivity Dilemma," The Academy of Management Review, 28(2): 238-256.

Berkowitz, M. (1987). "Product Shape as a Design Innovation Strategy," Journal of Product Innovation Management, 4: 274-283.

Bloch, P. H. (1995). "Seeking the Ideal Form: Product Design and Consumer Response," Journal of Marketing, 59(3): 16.

Chandy, R. K., and Tellis, G. J. (2000). "The incumbent's curse? Incumbency, size, and radical product innovation," Journal of Marketing, 64(3): 1-17.

Childers, T. L., Carr, C. L., Peck, J., and Carson, S. (2001). "Hedonic and utilitarian motivations for online retail shopping behavior," Journal of Retailing, 77(4): 511-535.

Creusen, M. E. H., and Schoormans, J. P. L. (2005). "The different roles of product appearance in consumer choice," Journal of Product Innovation Management, 22(1): 63-81.

Creusen, M. E. H., Veryzer, R. W., and Schoormans, J. P. L. (2010). "Product value importance and consumer preference for visual complexity and symmetry," European Journal of Marketing, 44(9): 1437-1452.

Crilly, N., Moultrie, J., and Clarkson, P. J. (2004). "Seeing things: Consumer response to the visual domain in product design," Design Studies, 25(6): 547-577.

Cyr, D., Head, M., and Ivanov, A. (2006). "Design aesthetics leading to m-loyalty in mobile commerce," Information and Management, 43(8): 950-963.

Dabholkar, P. A., and Bagozzi, R. P. (2002). "An attitudinal model of technology-based selfservice: Moderating effects of consumer traits and situational factors," Journal of the Academy of Marketing Science, 30(3): 184-201.

Davis, F. D. (1985). "A technology acceptance model for empirically testing new end-user information systems: Theory and results." (Doctoral dissertation, Massachusetts Institute of Technology).

Davis, F. (1989). "Perceived usefulness, perceived ease of use, and user acceptance of information technology," MIS Quarterly: Management Information Systems, 13(3): 319339. 
Davis, F., Bagozzi, R. P., and Warshaw, P. R. (1989). "User Acceptance of Computer Technology: A Comparison of Two Theoretical Models," Management Science, 35(8): 982-1003.

Davis, F., Warshaw, P., and Bagozzi, R. (1992). "Extrinsic and Intrinsic Motivation to Use Computers in the Workplace," Journal of Applied Social Psychology, 22(14): 1111-1132.

Demirbilek, O., and Sener, B. (2003). "Product design, semantics and emotional response," Ergonomics, 46(13-14): 1346-1360.

Dodds, B., W., Monroe, B. K. and Grewal D. (1991). "Effects of Price, Brand, and Store Information on Buyers' Product Evaluations," Journal of Marketing Research, 28 (3): 307-319.

Er, H. A. (1997). "Development patterns of industrial design in the Third World: A conceptual model for newly industrialized countries," Journal of Design History, 10(3): 293-307.

Fishbein, M., and Ajzen, I. (1975). Belief, Attitude, Intention, and Behavior: An Introduction to Theory and Research. Reading, MA: Addison-Wesley.

Fornell, C., and Larcker, D. F. (1981). "Structural equation models with unobservable variables and measurement error: Algebra and statistics," Journal of Marketing Research, 18(3): 382-388.

Gentry, L., and Calantone, R. (2002). "A Comparison of Three Models to Explain Shop-Bot Use on the Web," Psychology and Marketing, 19(11): 945-956.

GfK (Growth from Knowledge - Research Company) (2017) Press Release dated 24 Nov. 2017 Retrieved. https://www.gfk.com/fileadmin/user_upload/dyna_content/TR/GfK_TEMAX_Q3_2017 _Basin_Bulteni_.pdf

Goldenberg, J., Mazursky, D. and Solomon, S., (1999). "Toward identifying the inventive templates of new products: A channeled ideation approach," Journal of Marketing Research, 36 (May): 200-10.

Gümüş, B., and Gegez, E. E. (2020). "Design Newness Effects on Consumers' Hearts and Minds, and The Moderating Roles of Involvement and Risk Perceptions," Pazarlama ve Pazarlama Araştırmaları Dergisi, 26 (Mayıs):305-331.

Hair, J. F., Black, W. C., Babin, B. J., and Anderson, R. E. (2010). Multivariate Data Analysis. 7th ed., Location: Pearson Education.

Hauser, J., Tellis, G. J., and Griffin, A. (2006). "Research on innovation: A review and agenda for marketing science," Marketing Science, 25(6): 687-717.

Henderson, R. M., and Clark, K. B. (1990). "Architectural Innovation: The Reconfiguration of Existing Product Technologies and the Failure of Established Firms," Administrative Science Quarterly, 35(1): 9.

Hill, R. J., Fishbein, M., and Ajzen, I. (1977). "Belief, Attitude, Intention and Behavior: An Introduction to Theory and Research," Contemporary Sociology, 6(2): 244.

Hollins, B., and Pugh, S. (1990). Successful product design: What to do and when. London: Butterworths.

Holton, R. H. (1958). "The distinction between convenience goods, shopping goods, and specialty goods," Journal of Marketing, 23(1), 53-56. 
Hsiao, K. L. (2013). “Android smartphone adoption and intention to pay for mobile internet: Perspectives from software, hardware, design, and value," Library Hi Tech, 31(2): 216235.

Hu, L. T., and Bentler, P. M. (1999). "Cutoff criteria for fit indexes in covariance structure analysis: Conventional criteria versus new alternatives," Structural equation modeling: a multidisciplinary journal, 6(1): 1-55.

İslamoğlu, A.H. and Altunışık, R. (2013). Tüketici Davranışları (Consumer Behavior). İstanbul: Beta Basın Yayım.

Jensen, R. (1999), The Dream Society: How the coming shift from information to imagination will transform your business. New York: McGraw-Hill.

Kavak, B., and Sığındı, T., (2012). "Pazarlama'daki Ürün Sınıflandırmasına İlişkin Bir Yazın İncelemesi," Hacettepe Üniversitesi İktisadi Ve İdari Bilimler Fakültesi Dergisi, 30(1), 49-67.

Kim, K. J., Shin, D. H. and Park E., (2015). "Can Coolness Predict Technology Adoption? Effects of Perceived Coolness on User Acceptance of Smartphones with Curved Screens," Cyberpsychology, Behavior, and Social Networking, 18(9):528-533.

Kitapçı, O., and Dörtyol, I. T. (2009). "Tüketici Satin Alma Karar Sürecinde Aile Bireylerinin Etkileri: Kadının Değişen Rolü Sivas İlinde Bir Uygulama," Çukurova Üniversitesi Sosyal Bilimler Dergisi, 18(2): 331-348.

Ko, E., Sung, H. and Yoon, H. (2008). "The Effect of Attributes of Innovation and Perceived Risk on Product Attitudes and Intention To Adopt Smart Wear," Journal of Global Academy of Marketing Science, 18(2): 1-23.

Kohli, R., and Krishnamurti, R. (1987). "Heuristic Approach To Product Design," Management Science, 33(12): 1523-1533.

Kotler, P., and Armstrong, G. (2012). Principles of Marketing, 14th Edition. New Jersey: Pearson Prentice Inc.

Kotler, P., and Keller, K. L. (2012). Marketing Management, 14th Edition. Location: Editorial Pearson.

Krippendorff, K. (1989). "Product semantics: A triangulation and four design theories," Product semantic '89. Helsinki: Finland: University of Industrial Arts.

Kulviwat, S., Bruner II, G. C., Kumar, An, Nasco, S. A. and Clark, T., (2007). "Toward a Unified Theory of Consumer Acceptance Technology," Psychology and Marketing, 24(12): 1059-1084.

Lavie, T. and Tractinsky, N., (2004). "Assessing dimensions of perceived visual aesthetics of web sites," International Journal Human-Computer Studies, 60: 269-298.

Lee, S., Ha, S., and Widdows, R. (2011). "Consumer responses to high-technology products: Product attributes, cognition, and emotions," Journal of Business Research, 64(11): $1195-1200$.

Levy, D. S., and Lee, C. K. C. (2002). “The Influence of Family Members on Housing Purchase Decisions," Journal of Property Investment and Finance, 22(4): 320-338.

Lin, C., Shih, H., and Sher, P. J., (2007). "Integrating technology readiness into technology acceptance: The TRAM model," Psychology and Marketing, 24: 641-657. 
Luchs, M., and Swan, K. S. (2011). "Perspective: The emergence of product design as a field of marketing inquiry," Journal of Product Innovation Management, 28(3): 327-345.

Luck, D. J. (1959). “On the nature of specialty goods," Journal of Marketing, 24(1), 61-64.

Malhotra, N. K. (2010). Marketing Research: An Applied Orientation. 6th ed., New Jersey: Pearson Education.

Mandler, G. (1982) The Structure of Value: Accounting for taste. In: Clark, M.S. and Fiske, S.T., Eds., Affect and Cognition, Lawrence Erlbaum Associates, Hillsdale, 3-36.

Moreau, C. P., Lehmann, D. R. and Markman, A. B., (2001). "Entrenched knowledge structures and consumer response to new products," Journal of Marketing Research, 38 (February): $14-29$.

Mugge, R., and Dahl, D. W. (2013). "Seeking the ideal level of design newness: Consumer response to radical and incremental product design," Journal of Product Innovation Management, 30(S1), 34-47.

Mumcu, Y., and Kimzan, H. S. (2015). "The Effect of Visual Product Aesthetics on Consumers' Price Sensitivity," Procedia Economics and Finance, 26(15): 528-534.

Murphy, P. E., and Enis, B. M., (1986). "Classifying products strategically," Journal of Marketing, 50(3), 24-42.

Mutlu, B., and Er, A. (2003). "Design Innovation: Historical and Theoretical Perspectives on Product Innovation by Design," Proceedings of the 5th European Academy of Design Conference, (April), 1-22. Retrieved from http://www.ub.edu/5ead/PDF/1/MutluEr.pdf

Nanda, P., Bos, J., Kramer, K. L., Hay, C., and Ignacz, J. (2008). "Effect of smartphone aesthetic design on users' emotional reaction: An empirical study," TQM Journal, 20(4): $348-355$.

Nanda, D., Clark, H., and Billy, B. (2006). "Exploring Family Roles in Purchasing Decisions During Vacation Planning: Review and Discussions for Future Research," Journal of Travel and Tourism Marketing, 20(3/4): 107- 125.

Nussbaum, B. (1988). “Smart Design,” Business Week, (April 11), 102-17.

Okudan, G. E. and Tauhid, S. (2008). "Concept selection methods - a literature review from 1980 to 2008," International Journal of Design Engineering (IJDE), 1(3): 243 - 277.

Özbek, V., Alnıaçı, Ü., Koc, F., Akkılıç, M. E., and Kaş, E. (2014). “The Impact of Personality on Technology Acceptance: A Study on Smart Phone Users," Procedia - Social and Behavioral Sciences, 150(July): 541-551.

Özbek, V., and Koç, F. (2009). "Kırsal Kesimde ve Kentlerde Yaşayan Ailelerin Dayanıklı Tüketim Malları Satın Alma Kararlarının Karşılaştırılmasına Yönelik Bir Araştırma," Balikesir University Journal of Social Sciences Institute, 12(21): 139-156.

Park, Y., and Chen, J. V. (2007). "Acceptance and adoption of the innovative use of smartphone," Industrial Management and Data Systems, 107(9): 1349-1365.

Petkova, A., and Rindova, V. (2006). "When is a New Thing a Good Thing ? Technological Change, Product Form Design," International Conference in Lisbon, 18(2): 217-232.

Porter, M.E., (1980). Competitive Strategy. New York, NY: Free Press. 
Radford, S. K., and Bloch, P. H. (2011). "Linking innovation to design: Consumer responses to visual product newness," Journal of Product Innovation Management, 28(S1): 208220.

Rindova, V. P., and Petkova, A. P. (2007). "When is a new thing a good thing? Technological change, product form design, and perceptions of value for product innovations," Organization Science, 18(2): 217-232.

Sadik-Rozsnyai, O., and Bertrandias, L. (2019). "New technological attributes and willingness to pay: the role of social innovativeness," European Journal of Marketing, 53(6): 10991124.

Schmitt, B., Simonson, A., (1997). Marketing Aesthetics: The Strategic Management of Brands, Identity, and Image. New York: Free Press.

Talke, K., Salomo, S., Wieringa, J. E., and Lutz, A. (2009). "What about design newness? Investigating the relevance of a neglected dimension of product innovativeness," Journal of Product Innovation Management, 26(6): 601-615.

TSKB -Türkiye Sınai Kalkınma Bankası (Industrial Development Bank of Turkey) (2018) Sectoral Report dated February 2018. Retrieved from: http://www.tskb.com.tr/i/assets/document/pdf/beyaz-esya-sektorel-gorunum-subat2018.pdf

TÜİK -Türkiye İstatistik Kurumu (Turkish Statistical Institute) (2018) Marriage Statistics. Retrieved from: https://biruni.tuik.gov.tr/medas/?kn=112\&locale $=$ tr

Tzou, R. C., and Lu, H. P. (2009). "Exploring the emotional, aesthetic, and ergonomic facets of innovative product on fashion technology acceptance model," Behaviour and Information Technology, 28(4): 311-322.

Unger, D., and Eppinger, S. (2011). "Improving product development process design: A method for managing information flows, risks, and iterations," Journal of Engineering Design, 22(10): 689-699.

Van der Heijden, H. (2003). "Factors influencing the usage of websites: The case of a generic portal in The Netherlands," Information and Management, 40(6): 541-549.

Venkatesh, V. (1999). "Creation of favorable user perceptions: Exploring the role of intrinsic motivation," MIS Quarterly: Management Information Systems, 23(2): 239-260.

Venkatesh, V., and Davis, F. D. (2000). "Theoretical extension of the Technology Acceptance Model: Four longitudinal field studies," Management Science, 46(2): 186-204.

Verganti, R. (2008). "Design, meanings, and radical innovation: A metamodel and a research agenda," Journal of Product Innovation Management, 25(5): 436-456.

Veryzer, R. (1993). "Aesthetic response and the influence of design principles on product preferences," Advances in Consumer Research, 20(1): 224-228.

Veryzer, R. W. and Hutchinson J. W., (1998). "The Influence of Unity and Prototypicality on Aesthetic Responses to New Product Designs," Journal of Consumer Research, 24(4): 374-394.

Walsh, V., Roy, R. and Bruce M. (1988). “Competitive by design,” Journal of Marketing Management, 4(2): 201-216.

Wang, D., Xiang, Z., Fesenmaier, D.R., (2014). "Adapting to the mobile world: a model of smartphone use," Ann. Tourism Res, 48: 11-26. 
Yang, H., Yu, J., Zo, H., and Choi, M. (2016). "User acceptance of wearable devices: An extended perspective of perceived value," Telematics and Informatics, 33(2): 256-269.

Yücel, U. A. and Gülbahar Y., (2013), "Technology Acceptance Model: A Review of the Prior Predictors, Ankara University," Journal of Faculty of Educational Sciences, 46(1):89109. 